Reprod. Nutr. Dévelop., 1983, 23 (2 A), 183-194.

\title{
Glucagon binding to purified liver plasma membranes from growing rats undergoing energy restriction
}

\author{
Michèle BALAGE, J. GRIZARD (1), R. PION \\ with the technical assistance of A. SELLE and M. SALLAS \\ Laboratoire d'Etude du Métabolisme azoté, I.N.R.A. \\ Theix, Saint-Genès-Champanelle, 63110 Beaumont, France
}

Summary. The purpose of this work was to investigate liver glucagon receptors in growing rats fed a control diet $(11.8 \%$ crude protein) or a high-protein diet $(19.8 \%$ crude protein) given in restricted amounts. The animals were fed every 4 hours. ${ }^{125}$ I-glucagon binding to purified liver plasma membranes was studied. Membrane purity was analysed with marker enzymes. The alteration of glucagon during incubation was measured. The results show that specific ${ }^{125} \mathrm{I}$-glucagon binding increased with time at $30^{\circ} \mathrm{C}$, reaching a maximal value within $120 \mathrm{~min}$. The increasing level of unlabelled glucagon inhibited ${ }^{125}$ glucagon binding at steady state. Apparent specific ${ }^{125} /$-glucagon binding at steady state was lower in experimental animals than in controls. This correlated with the increase in glucagon breakdown and decrease in membrane purity. Alternatively, glucagon binding to its receptors could drop. Unlabelled glucagon excess produced a time-dependent dissociation of glucagon-receptor complexes (half-life : up to $1 \mathrm{~h}$ ). Feeding the experimental diet increased the dissociation of labelled glucagon-receptor complexes.

\section{Introduction.}

Glucagon promotes amino acid extraction by the liver and amino acid breakdown. Furthermore, it decreases liver protein synthesis (Ayuso-Parilla et al., 1976 ; Martin-Requero et al., 1979). Glucagon binding to cell surface receptors is generally believed to be the initial step in glucagon action, controlling the latter in vitro. A decrease in glucagon binding to its liver receptors accompanies a decrease in glucagon action in fasted rats (Fouchereau-Peron et al., 1976 ; Broer et al., 1977). However, glucagon binding does not always correlate with glucagon sensitivity status in hyperglucagonemic and fasted rodents (Srikant et al., 1977 ; Caro and Amatruda, 1980).

The present study was designed to investigate glucagon binding to purified liver plasma membranes from growing rats subjected to a high protein diet given in restricted amounts. This nutritional status has been poorly studied. It produces

(1) To whom reprint requests should be addressed. 
a drop in growth rate and in the growth rate/crude protein intake ratio (Rérat and Desmoulin, 1970). Body composition is also modified (Grizard et al., 1975). Muscle protein synthesis decreases, whereas liver protein synthesis increases (Arnal et al., 1972). Amino acid breakdown and the conversion of amino acids into glucose are enhanced (Grizard et al., 1975). These changes indicate that there may also be variations in the hormonal mechanisms controlling protein metabolism in liver and muscle. For example, blood insulin decreases but liver insulin receptors increase in growing rats (Grizard, Arnal and Pion, 1980).

Some of the present work has been reported previously in an abstract (Balage and Grizard, 1981).

\section{Material and methods.}

Animals and treatments. - A control and an experimental group of 15 male Sprague-Dawley rats each, weighing about $50 \mathrm{~g}$, were purchased and housed individually in cages maintained under controlled environmental conditions $\left(22{ }^{\circ} \mathrm{C}, 60 \%\right.$ relative humidity, 12 -hour dark period starting at 10 a.m.). They were fed a standard diet and then a control diet until a weight of $100 \mathrm{~g}$ was reached. The controls were then fed the control diet $(11.8 \%$ crude protein), whereas the experimental animals were fed the high-protein $119.8 \%$ crude protein), high-mineral, high-vitamin, low-carbohydrate diet. The food intake of the experimental group was restricted to $66 \%$ of that of the controls (table 1). Thus, they received slightly higher daily amounts of crude protein, mineral and vitamins than the controls $(+12 \%)$. Daily intake of carbohydrate, lipid and indigestible agar-agar was reduced $(-34,-44$ and $-34 \%$, respectively). The experimental animals grew $45 \%$ more slowly than the controls. Crude protein efficiency (i.e. the growth rate/crude protein intake ratio) was highly impaired, suggesting an increased rate of amino acid breakdown and gluconeogenesis (Grizard et al., 1975). The control and the high-protein diets, which have been described previously (Grizard et al., 1975; Grizard, Arnal and Pion, 1980),

TABLE 1

Animal parameters

\begin{tabular}{lcc}
\hline \multicolumn{1}{c}{ Group } & Control & Experimental \\
\hline $\begin{array}{l}\text { Number of animals } \\
\text { Number of experimental days }\end{array}$ & 15 & 15 \\
Liveweight on the day of sacrifice (g) & 11 & $18-20$ \\
Daily gain $(\mathrm{g})$ & $161 \pm 6$ & $155 \pm 4$ \\
Daily intakes : & $6.29 \pm 0.37$ & $3.45 \pm 0.43^{*}$ \\
$\quad$ dry matter (g) & $15.6 \pm 0.6$ & $10.5 \pm 0.2$ \\
$\quad$ crude protein (g) & $1.84 \pm 0.07$ & $2.07 \pm 0.03^{*}$ \\
$\quad$ crude energy (K Joules) & $282 \pm 10$ & $188 \pm 3^{*}$ \\
Liver weight $(\mathrm{g})$ & $7.32 \pm 0.35$ & $6.27 \pm 0.30^{*}$ \\
\end{tabular}

Each value is the mean $\pm S D$

* : significantly different $(P \leqslant 0.050)$ from the controls. 
contained fish meal supplemented with methionine, phenylalanine, tryptophane and threonine. The animals were fed on an automatic feeding schedule. Beginning at 10 a.m., they consumed each of the six equal meals (given every $4 \mathrm{~h}$ ) within about $5 \mathrm{~min}$. When they had attained a mean body weight of $155 \mathrm{~g}$, they were killed without anaesthesia at approximate 15-min intervals between 2 p.m. and 4 p.m. Seven representative rats from each group were used to study liver glucagon receptors.

Chemicals. - Highly purified porcine glucagon (G 501575) was obtained from the Novo Research Institute, Bagsvaerd, Denmark. ${ }^{125}$-Na (IMS. 30) was purchased from the Radiochemical Center, Amersham, England. Bovine serum albumine (fraction V) was purchased from Calbiochem; 5'-AMP was from Merck, and D-glucose-6-phosphate, thymidine $5^{\prime}$-monophospho-p-nitro phenyl ester, p-nitrophenol and aprotinin from the Sigma Chemical Company.

125I-glucagon was prepared according to the method of Nottey and Rosselin (1971) and was purified by chromatography on a DEAE cellulose column. This preparation contained about $5-30 \%$ of ${ }^{125}$-glucagon and $70-95 \%$ of unlabelled glucagon since average specific activity was within $30-200 \mu \mathrm{Ci} / \mu \mathrm{g}$, as measured by the trichloracetic acid method. Monoiodoglucagon had been shown previously (Fuller et al., 1975; Desbuquois, 1975) to be biologically active and its interaction with the receptor is indistinguishable from that of native glucagon.

Liver plasma membranes. - Fully purified liver plasma membranes were prepared (Neville, 1968, step 15) with the following modifications; the livers were quickly removed, weighed and freeze-stopped in liquid nitrogen within 2$3 \mathrm{~min}$. They were kept at $-80^{\circ} \mathrm{C}$ during a 2-week period. Pooled samples of livers from the same group were then thawed within $2-5$ min in $1 \mathrm{mM} \mathrm{Na} \mathrm{HCO}$ at $4{ }^{\circ} \mathrm{C}$. Quick freezing and quick thawing induced no detectable variations in liver fractions as judged by electron microscopy, chemical composition and enzymatic criteria (Fleischer and Kervina, 1974). 5'-Nucleotidase activity and insulin receptors remained unchanged, whereas glucagon binding to its receptors was significantly reduced (Balage and Grizard, unpublished results). Purified plasma membranes were stored at $-80^{\circ} \mathrm{C}$ until use. Protein concentration was determined (Lowry et al., 1951) using bovine albumin as a standard. The activity of $5^{\prime}$-nucleotidase, the standard marker for plasma membranes, was determined by measuring the rate of inorganic phosphate release from $5^{\prime}$-AMP. Both soluble phosphodiesterase activity and that located in membrane particles were determined by measuring the release rate of $p$-nitrophenol from thymidine $5^{\prime}$ monophospho-p-nitrophenyl ester. Glucose-6-phosphatase activity, a standard microsomal marker, was evaluated by measuring the release rate of inorganic phosphate from D-glucose-6-phosphate (Aronson and Touster, 1974).

Binding studies. - Studies of ${ }^{125} \mathrm{I}$-glucagon binding were conducted according to the procedure of Freychet et al. (1974) and Broer et al. (1977) with some minor modifications. Incubation was performed at $30{ }^{\circ} \mathrm{C}$ in Krebs-Ringer phosphate buffer $\left(40 \mathrm{mM} \mathrm{NaCl}, 1.7 \mathrm{mM} \mathrm{KCl}, 0.4 \mathrm{mM} \mathrm{MgSO}_{4}, 0.4 \mathrm{mM} \mathrm{KH}_{2} \mathrm{PO}_{4}\right.$, $\mathrm{pH}$ 7.5) with membrane protein at $0.13-0.15 \mathrm{mg} / \mathrm{ml}$, bovine serum albumin at $10 \mathrm{mg} / \mathrm{ml}$, bacitracin at $0.1 \mathrm{mg} / \mathrm{ml}$ and aprotinin at $2000 \mathrm{IU} / \mathrm{ml}$ in a final volume of 
$0.275 \mathrm{ml}$ per incubation tube. The incubation mixture also contained ${ }^{125}$-glucagon at $0.3-2.5 \mathrm{nM}$ and unlabelled glucagon at $0-500 \mathrm{nM}$. Dissociation of the $125-$ glucagon-membrane-receptor complexes was measured after unlabelled hormone excess was added when ${ }^{125}$ I-glucagon binding was in a steady state. At the times indicated in the figure legends, incubation was ended by cooling the incubation tubes in an ice bath. $1 \mathrm{ml}$ of chilled buffer was added to each incubation tube, then $1 \mathrm{ml}$ of the mixture was transferred to chilled plastic microfuge tubes. The latter tubes were centrifuged for $6 \mathrm{~min}$ at $25000 \times \mathrm{g}$ at $4{ }^{\circ} \mathrm{C}$. The supernates were sucked out and pellet radioactivity counted. Total binding referred to the radioactivity of the pellet, whereas non-specific binding referred to pellet radioactivity along with a great excess of unlabelled hormone $(14.9 \mu \mathrm{M})$. Specific binding was the difference between total and non-specific binding. Specific ${ }^{125}$ glucagon binding was normalized to $0.1 \mathrm{mg}$ of membrane protein per $\mathrm{ml}$ in all experiments. With the concentrations of membrane protein used in this experiment, specific ${ }^{125}$-glucagon binding to liver plasma membranes from rats fed a standard diet ad libitum, was a linear function of membrane protein concentration (Balage, unpublished results).

Unaltered glucagon. - ${ }^{125}$-glucagon, which remained intact in the supernate from the incubation mixtures (glucagon at 2.7 and $5.0 \mathrm{nM}$ ), was evaluated by measuring its ability to rebind to fresh membranes.

Analysis of data. - Equilibrium binding parameters were calculated by Scatchard analysis. We used linear regression of the ratio of bound to free glucagon (B/F) as a function of bound glucagon (B). The slope was the affinity constant and the intercept with the horizontal axis was the binding capacity. With high glucagon levels $(1.5-500 \mathrm{nM})$, regression gave the low-affinity constant and total binding capacity (low-affinity + high-affinity receptors). With low glucagon levels and using data corrected for the contribution of low-affinity receptors, regression gave the affinity constant and the binding capacity of highaffinity receptors. The dissociation rate was obtained for the first part $(0-30 \mathrm{~min})$ of the dissociation curve by the linear regression slope of specific ${ }^{125}$-glucagon binding logarithm vs time after the addition of unlabelled glucagon.

Statistical methods. - The "goodness of fit " of linear unweighted regressions was assessed by the F-test. Differences between the regressions were tested for significance by covariance analysis. Differences between the means were tested for significance by variance analysis (Snedecor and Cochran, 1971). Because samples from each group were pooled, standard deviations and standard errors referred to measurements but not to individuals.

\section{Results.}

Time course of binding. - The time course of specific ${ }^{125}$-glucagon binding to purified liver plasma membranes was the same in the two groups when normalized to the same maximal binding (fig. 1). It was slower than that reported previously with isolated hepatocytes (Broer et al., 1977; Gill and Hart, 1980). Specific ${ }^{125}$-glucagon binding increased rapidly after incubation began, attaining half-maximal binding within $45 \mathrm{~min}$. Afterwards, this specific binding increased 


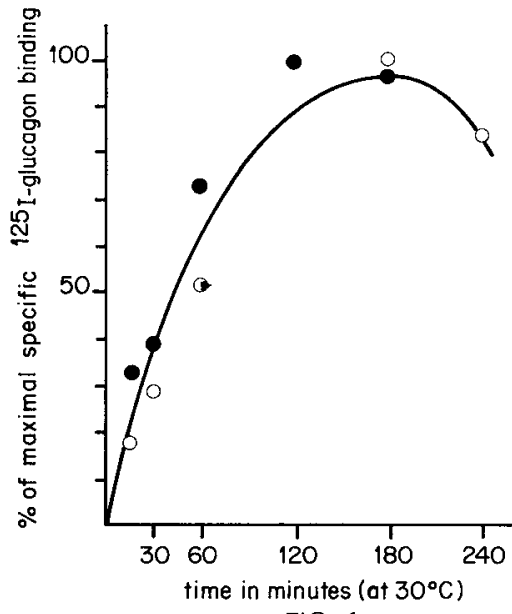

FIG. 1.

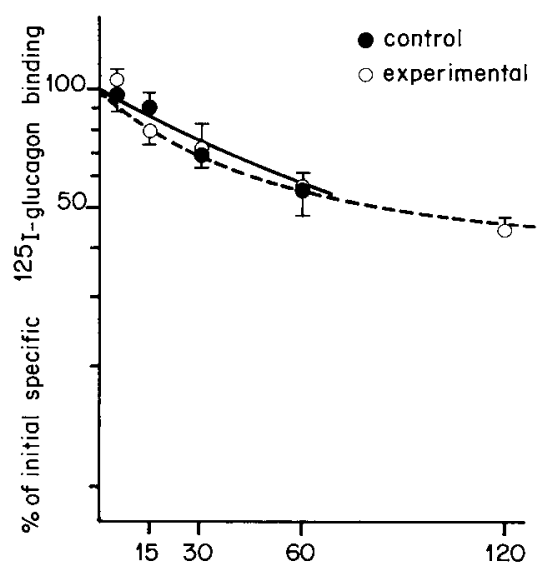

duration of dissociation (in min. at $30^{\circ} \mathrm{C}$ )

FIG. 2.

FIG. 1. - Time course of ${ }^{125} /$ glucagon binding to purified liver plasma membranes. ${ }^{125} \mathrm{I}$-glucagon $(2.5 \pm 0.1 \mathrm{nM})( \pm \mathrm{SD})$ was allowed to bind at $30^{\circ} \mathrm{C}$ to membranes (membrane protein : $0.14 \pm 0.02 \mathrm{mg} / \mathrm{ml}$ ) at the times indicated. Specific ${ }^{125}$ I-glucagon binding in each group was plotted as the percentage of maximal specific ${ }^{125}$-glucagon binding. Average maximal specific ${ }^{125}$-glucagon binding was $0.10 \mathrm{pM} / 0.1 \mathrm{mg}$ of membrane protein. Non-specific binding $11.4 \pm 0.1 \%$ of labelled hormone introduced into the incubation tube $/ 0.1 \mathrm{mg}$ of membrane protein), subtracted from each point, was measured in simultaneous experiments. Each value is the mean of duplicate determinations for one experiment.

FIG. 2. - Time course of dissociation of $125 /$ g/ucagon from purified liver plasma membranes. Liver plasma membranes were incubated at $30^{\circ} \mathrm{C}$ in two steps : (1) ${ }^{125} \mathrm{I}$-glucagon $(2.16 \pm 0.05 \mathrm{nM})$ $( \pm \mathrm{SD})$ was aflöwed to bind to membranes (membrane protein : $0.15 \pm 0.02 \mathrm{mg} / \mathrm{ml}$ ) for $120 \mathrm{~min}$; (2) the second step was then initiated immediately (time 0 on the figure) by adding unlabelled hormone (in $50 \mu \mathrm{l}$ ) to obtain a final concentration of $14.9 \mu \mathrm{M}$. Bound radioactivity was measured at the indicated times. Non-specific binding $11.4 \pm 0.4 \%$ of labelled hormone introduced into the incubation tube $/ 0.1 \mathrm{mg}$ of membrane protein), subtracted from each point, was measured in simultaneous experiments. The results in each group are expressed as the percentage of specific ${ }^{125} \mathrm{I}$-glucagon binding at starting time. Each value is the mean $\pm \mathrm{SE}$ of duplicate determinations in one experiment.

slowly, maximal binding occurring after 120-180 min. After $180 \mathrm{~min}$, specific binding began to decline.

Dissociation of glucagon-membrane receptor complexes. - In the 30-min period after glucagon excess was added, ${ }^{125}$-glucagon dissociated more rapidly in experimental rats than in controls (fig. 2), suggesting an increase in the dissociation rate constant (table 2). Afterwards, the dissociation rate dropped in both groups.

Specific glucagon binding at steady state. - Specific 125/-glucagon binding decreased with increasing glucagon. With low glucagon (0.3-5 $\mathrm{nM}$ ) it was lower in the experimental animals than in the controls (fig. 3). Regression analysis exhibited significant differences $(p<0.05)$ between the two competitioninhibition curves. In contrast, with high glucagon, specific $125 \mathrm{~J}$-glucagon was similar in both groups. The glucagon level for half-maximal binding was within 9$11 \mathrm{nM}$. 
Calculated affinity constants and binding capacities exhibited no significant differences in the two groups (table 2). As previously observed by Giorgio, Johnson and Blecher (1974), Fouchereau-Peron et al. (1976), Caro and Amatruda (1980), Bhatena et al. (1978) and Sonne et al., (1981), Scatchard analysis gave a curvilinear plot (fig. 3) consistent with two classes of independent binding sites. Alternatively, curvilinear Scatchard could result from site-site interactions. This seems unlikely since the dissociation rate of ${ }^{125} \mathrm{I}$-glucagon, produced by " infinite » dilution, is not significantly increased further by unlabelled glucagon in liver plasma membranes (Balage, unpublished results) and isolated hepatocytes (Sonne et al., 1978 ; Fehlmann et al., 1981). The affinity constants and binding capacities of high-affinity receptors were in good agreement with published data (Gill and Hart, 1980 ; Srikant et al., 1977 ; Fouchereau-Peron et al., 1976 ; Sonne et al., 1978). However, because glucagon binding to its receptors is a complex reaction (Blake, 1978), the meaning of the kinetic parameters of glucagon binding must be considered critically.

TABLE 2

Parameters of glucagon binding

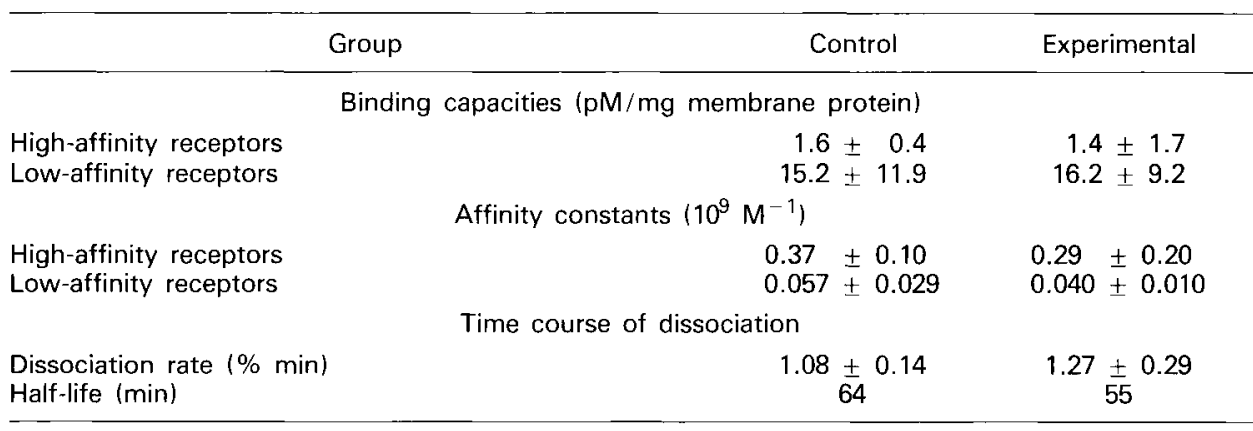

Each value is the mean \pm the standard deviation of the regression coefficient (affinity constants, dissociation rate constant) or the mean \pm the standard error of the prediction by regression (binding capacities).

Unaltered glucagon. - Differences in the unaltered hormone might have affected the apparent values of hormone binding. Glucagon was significantly altered in the experimental rats compared to the controls (table 3). This fully correlated with the decrease in apparent specific ${ }^{125} \mathrm{I}$-glucagon binding. However, the meaning of altered glucagon is unclear, and breakdown was not taken into account when glucagon binding was calculated.

Characteristics of plasma membrane preparations. - Recovery of glucose-6phosphatase from membrane preparations was low, indicating that there was no microsomal contamination (table 4). Recovery of 5'-nucleotidase and phosphodiesterase was similar in both groups. This finding suggests that the differences observed in glucagon binding are not attributable to differences in membrane recovery. However, 5'-nucleotidase and phosphodiesterase activities per $\mathrm{mg}$ of membrane protein were lower in the experimental animals than in the controls. 


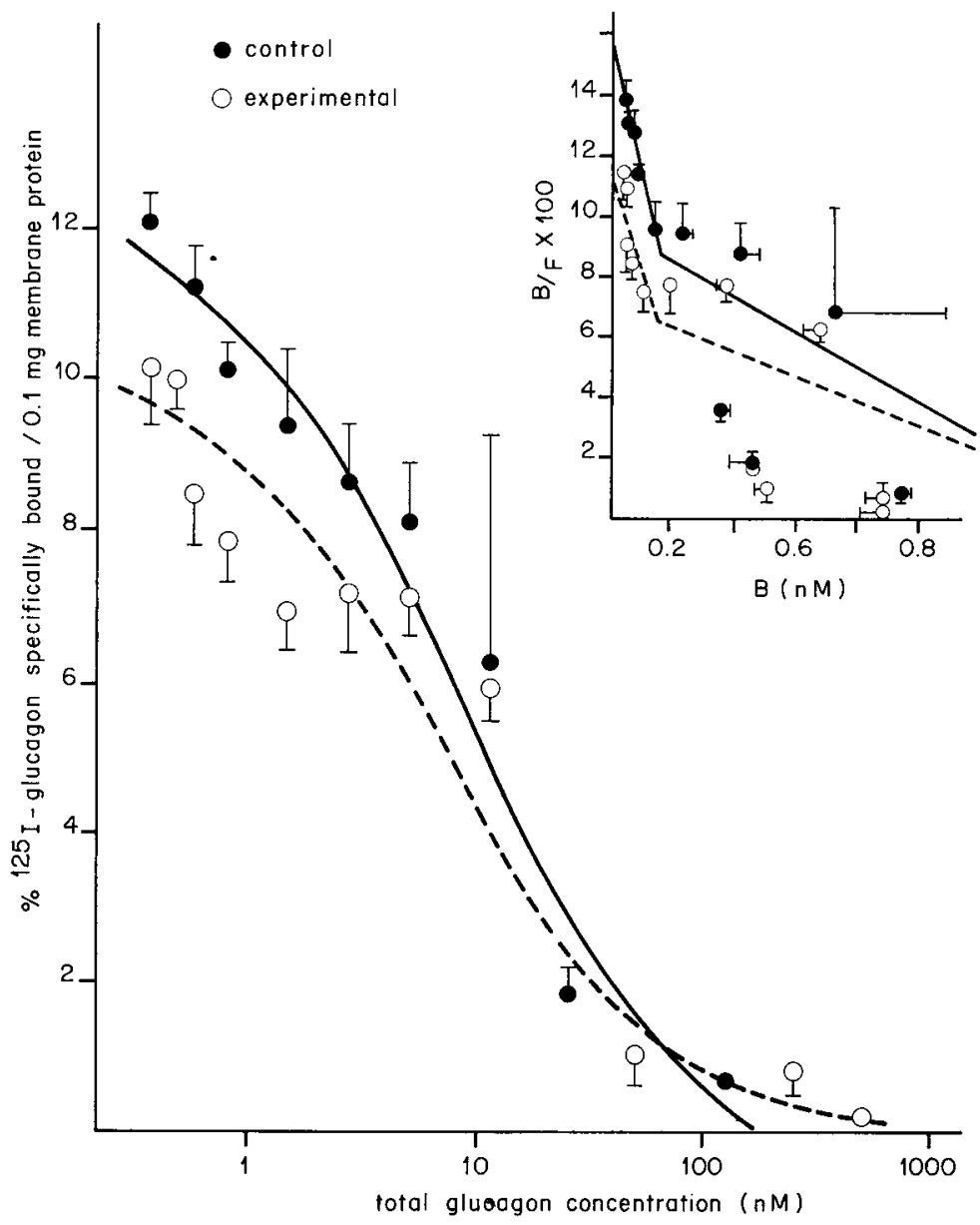

FIG. 3. - Glucagon binding at steady state to purified liver plasma membranes as a function of total g/ucagon concentration. ${ }^{125}$ I-glucagon $(0.32 \pm 0.01 \mathrm{nM})( \pm \mathrm{SD})$ and unlabelled glucagon $(0$ to $500 \mathrm{nM})$ were allowed to bind to membranes (membrane protein : $0.15 \pm 0.02 \mathrm{mg} / \mathrm{ml}$ ) for $120 \mathrm{~min}$ at $30^{\circ} \mathrm{C}$. The results concern the percentage of specific ${ }^{125} \mathrm{I}$-glucagon membrane binding at $0.1 \mathrm{mg} / \mathrm{ml}$ of membrane protein. Non-specific binding $(1.5 \pm 0.3 \%)$, subtracted from each point, was measured simultaneously. Each point is the mean $\pm \overline{S E}$ for three separate experiments. Duplicate or triplicate incubations were carried out in each experiment.

In the insets, the same data are expressed using the method of Scatchard, i.e. the ratio of bound to free ${ }^{125} \mathrm{l}$-glucagon $(\mathrm{B} / \mathrm{F})$ is plotted as a function of the quantity of glucagon bound (B) to liver plasma membranes. Bound glucagon $=$ (percentage of ${ }^{125}$ /-glucagon specifically bound) $x$ (total glucagon concentration). The lines represent calculated regressions of $(B / F)$ vs $(B)$ with low and high glucagon, respectively.

This correlated with the increase in protein yield. Therefore, the drop in apparent specific ${ }^{125}$-glucagon binding per $\mathrm{mg}$ of purified liver plasma membranes could be explained by a drop in membrane purity. Alternatively, $5^{\prime}$-nucleotidase activity could have decreased as a result of energy restriction (Grizard, Arnal and Pion, 1980). 
TABLE 3

Unaltered hormone

\begin{tabular}{lccc} 
& Group & Control & Experimental \\
\hline Glucagon $(2.7 \mathrm{nM})$ & $123 \pm 27$ & $89 \pm 3^{\text {(a) }}$ \\
Glucagon $(5.0 \mathrm{nM})$ & $142 \pm 28$ & $82 \pm 6^{\text {(a) (b) }}$ \\
\hline
\end{tabular}

$125 \mathrm{I}$-glucagon (at 2.7 and $5.0 \mathrm{nM}$ ) was allowed to bind to the membranes (membrane protein at 0.16 $\pm 0.02 \mathrm{mg} / \mathrm{ml}$ ) for $120 \mathrm{~min}$ at $30^{\circ} \mathrm{C}$ (see Methods). ${ }^{125}$ I-glucagon remaining intact in the supernates from the incubation mixtures was evaluated by measuring its ability to rebind to fresh membranes. Results refer to the percentage of unaltered glucagon present in controls simultaneously incubated without membranes. Each value is the mean $\pm S D$ of quadriplicate determinations for one experiment.

(a) value significantly different $(P<0.05)$ from $100 \%$.

(b) experimental group values were significantly different $(P<0.05)$ from the corresponding control group values.

TABLE 4

Enzymatic activities in homogenate and liver plasma membrane preparations

\begin{tabular}{|c|c|c|c|}
\hline & Group & Control & Experimental \\
\hline \multicolumn{4}{|c|}{ Membrane protein recovery (mg/g wet liver) } \\
\hline & & $0.18 \pm 0.01$ & $0.32 \pm 0.02$ \\
\hline \multicolumn{4}{|c|}{$5^{\prime}$-nucleotidase } \\
\hline $\begin{array}{l}\text { Homogenate } \\
\text { Membrane } \\
\% \text { recovery }\end{array}$ & & $\begin{array}{c}4.00 \pm 0.22 \\
61.5 \pm 1.1 \\
2.3\end{array}$ & $\begin{array}{c}4.80 \pm 0.20 \\
31.8 \pm 0.4 \\
2.8\end{array}$ \\
\hline \multicolumn{4}{|c|}{ Phosphodiesterase } \\
\hline $\begin{array}{l}\text { Homogenate } \\
\text { Membrane } \\
\% \text { recovery }\end{array}$ & & $\begin{array}{c}0.73 \pm 0.07 \\
16.4 \pm 0.2 \\
3.3\end{array}$ & $\begin{array}{c}1.46 \pm 0.06 \\
12.9 \pm 0.4 \\
3.7\end{array}$ \\
\hline \multicolumn{4}{|c|}{ Glucose-6-phosphatase } \\
\hline $\begin{array}{l}\text { Homogenate } \\
\text { Membrane } \\
\% \text { recovery }\end{array}$ & & $\begin{array}{c}10.0 \pm 0.9 \\
5.4 \pm 0.1 \\
0.08\end{array}$ & $\begin{array}{c}10.4 \pm 0.2 \\
1.5 \pm 0.1 \\
0.06\end{array}$ \\
\hline
\end{tabular}

$5^{\prime}$-Nucleotidase and glucose 6-phosphatase activities were expressed in micromoles of inorganic phosphate/mg of protein/hour. Phosphodiesterase activity was expressed in micromoles of pnitrophenol $/ \mathrm{mg}$ of protein/hour. Each value is the mean \pm SD of triplicate determinations.

\section{Discussion.}

Feeding the experimental diet produced a significant decrease in apparent specific ${ }^{125} \mathrm{I}$-glucagon binding to purified liver plasma membranes. There are several factors which might account for- this decrease. The breakdown rate of ${ }^{125} \mathrm{I}$-glucagon was enhanced since the percentage of hormone remaining intact in the supernate of incubation mixtures dropped. Furthermore, as seen from marker 
enzyme measurement, membrane purity decreased. Thus, specific glucagon binding to its receptors could have dropped. As measurement of the dissociation of ${ }^{125} \mathrm{I}$-glucagon complexes (induced by unlabelled glucagon excess) showed, there was an increase in the dissociation rate constant. Scatchard analysis of equilibrium binding data exhibited no further decreases in affinity constants and binding capacities.

The decrease in glucagon binding to its receptors after feeding the experimental diet correlates with the decrease in glucagon binding found in fasted rats (Fouchereau-Peron et al., 1976 ; Broer et al., 1977 ; Caro and Amatruda, 1980 ; Srikant et al., 1977 ; Freeman et al., 1977). It contrasts with the constant, glucagon binding to isolated hepatocytes found in restricted goats (Gill and Hart, 1979 ; Gill and Hart, 1981). It probably parallels an increase in circulating blood glucagon since hyperglucagonemia (following exogenous administration of glucagon and observed in spontaneous obesity) induces a drop in glucagon binding to hepatocytes and liver plasma membranes (Bhatena et al., 1978 ; Srikant et al., 1977). Furthermore, fasting, energy restriction or high-protein diets have been known to increase blood glucagon in different species (Unger, 1972; Eisenstein and Strack, 1978 ; Eisenstein et al., 1979 ; Jarrousse et al., 1980 ; Peret et al., 1981 ; Aguilar-Parada et al., 1969 ; Gerich, 1976). The age increment from the controls to the experimental animals cannot explain this since glucagon binding to its liver receptors is unaltered or increased from neonatal to adult rats (Lockwood and East, 1978; Basquez et al., 1976 ; Pingoud et al., 1982).

Decreased glucagon binding after feeding the experimental diet could not explain the increase in amino acid breakdown observed in such animals (Grizard et al., 1975) since glucagon promoted amino acid extraction by the liver and amino acid conversion into glucose. Several factors could explain this discrepancy. First, glucagon binding does not always correlate with the status of glucagon sensitivity. Indeed, a decrease in glucagon binding induces a decrease in glucagon sensitivity in fasted rats, as far as cyclic AMP production by the liver is concerned (Broer et al., 1977 ; Fourchereau-Peron et al., 1976). In contrast, other authors (Caro and Amatruda, 1980 ; Freeman et al., 1977 ; Srikant et al., 1977) found no subsequent modification in glucagon-stimulated amino acid transport and cyclic AMP production after glucagon binding decreased. In the latter case, the reduction of binding sites might have been restricted to those not involved in biological action (Birnbaumer and Pohl, 1973) or else the biological action generated by the receptors was enhanced. Secondly, circulating glucagon might increase (see above). Another possibility would be that hormones other than glucagon vary. Feeding the experimental diet also induced a small increase in insulin binding to liver plasma membranes (Grizard, Arnal and Pion, 1980). These results are in keeping with the increase in protein anabolism observed in livers from such animals (Arnal et al., 1972) since glucagon produces a drop in liver protein anabolism (Ayuso-Parrilla et al., 1976 ; Martin-Requero et al., 1979), whereas insulin promotes it (Bellemann et al., 1977). 
Résumé. Influence de la restriction énergétique sur les récepteurs de glucagon dans le foie chez le rat en croissance.

Le but du présent travail est l'étude des récepteurs de glucagon dans le foie chez le rat en croissance soumis ou non à une restriction énergétique. Pour cela, des rats mâles de souche Sprague-Dawley sont répartis en deux lots. Le lot Témoin reçoit un régime équilibré à $11,8 \%$ de protéines ; le lot soumis à la restriction énergétique reçoit en quantité limitée un régime riche en protéines $(19,8 \%$ de protéines). L'aliment est distribué en 6 repas égaux régulièrement répartis au cours du nycthémère. Les rats sont sacrifiés au poids moyen vif de $155 \mathrm{~g}$. Les membranes plasmiques du foie sont préparées selon la méthode de Neville, leur degré de purification est déterminé par les activités $5^{\prime}$ nucléotidase et phosphodiesterase. La fixation du glucagon aux membranes est mesurée au moyen de ${ }^{125}$-glucagon. Le glucagon intact au terme des incubations est déterminé par sa capacité à se fixer à nouveau à des membranes plasmiques.

A $30^{\circ} \mathrm{C}$ la fixation spécifique apparente du ${ }^{125} \mathrm{I}$-glucagon aux membranes augmente en fonction de la durée d'incubation, elle atteint un maximum à partir d'une durée d'incubation voisine de $2 \mathrm{~h}$. Pour une concentration constante en ${ }^{125} \mathrm{I}$-glucagon, cette valeur maximum diminue à mesure que la concentration en glucagon non radioactif augmente. De plus, lorsque ce maximum de fixation est atteint, un excès de glucagon non radioactif entraîne une dissociation de la fixation du ${ }^{125} \mathrm{I}$-glucagon aux membranes selon une période de demi-vie d'environ 1 heure.

La fixation spécifique apparente du ${ }^{125} /$-glucagon aux membranes est plus faible chez les rats soumis à la restriction énergétique que chez les rats témoins. Ceci est en accord d'une part avec la diminution de l'hormone intacte au terme des incubations et d'autre part avec la réduction de la pureté des membranes observée chez les animaux restreints en énergie. Ceci peut aussi traduire une réduction de la fixation du glucagon à ses récepteurs sous l'effet de la restriction énergétique. De plus, la vitesse de dissociation du ${ }^{125}$ glucagon fixé aux membranes est plus rapide chez les rats soumis à la restriction énergétique que chez les rats témoins.

\section{Références}

AGUILAR-PARADA E., EISENTRAUT A. M., UNGER R. H., 1969. Effects of starvation on plasma pancreatic glucagon in normal man. Diabetes, 18, 717-723.

ANTHONY L. E., FALOONA G. R., 1974. Plasma insulin and glucagon levels in proteinmalnourished rats. Metabolism, 23, 303-306.

ARNAL M., FAUCONNEAU G., PECH R., 1972. Synthèses protéiques in vivo dans divers tissus du rat en croissance soumis à une réduction de l'apport énergétique de la ration. Ann. Biol. anim. Bioch. Biophys., 12, 91-108.

ARONSON N. N., TOUSTER O., 1974. Isolation of rat liver plasma membrane fragments in isotonic sucrose. In FLEISCHER S., PACKER L., Methods in Enzymology, vol. 31, part A, p. 90. Acad. Press, New York, San Francisco, London.

AYUSO-PARRILLA M. S., MARTIN-REQUERO A., PEREZ DIAZ J., PARILLA P., 1976. Role of glucagon on the control of hepatic protein synthesis and degradation in the rat in vivo. J. biol. chem., 251, 7785-7790.

BALAGE M., GRIZARD J., 1981. Influence de la restriction énergétique sur les récepteurs du glucagon dans le foie chez le rat en croissance. $7^{e}$ Réun. Assoc. Fr. Nutr., Paris.

BELLEMANN P., FRY J. R., BRIDGES J. W., SCHLOTE W., MECKE D., 1977. Effect of insulin on glycogen and protein synthesis in monolayer cultures of hepatocytes from normal and alloxan diabetic rats. Diabetologia, 13, 621-628.

BHATENA S. J., VOYLES N. R., SMITH S., RECANT L., 1978. Decreased glucagon receptors in diabetic rat hepatocytes. Evidence for regulation of glucagon receptors by hyperglucagonemia. J. clin. Invest., 61, 1488-1497. 
BIRNBAUMER L., POHL S. L., 1973. Relation of glucagon-specific binding sites to glucagondependent stimulation of adenyl-cyclase activity in plasma membrane of rat liver. $\mathrm{J}$. biol. Chem., 248, 2056-2061.

BLAKE C. C. F., 1978. Hormone receptors. Endeavour, New Ser., 2, 137-141.

BLASOUEZ E., RUBALCAVA B., MONTESANO R., ORCI L., UNGER R. H., 1976. Development of insulin and glucagon binding and the adenylate cyclase response in liver membranes of the prenatal, postnatal, and adult rat : Evidence of glucagon " resistance ". Endocrinology, 98, 1014-1023.

BROER Y., FREYCHET P., ROSSELIN G., 1977. Insulin and glucagon-receptor interactions in the genetically obese Zucker Rat: Studies of hormone binding and glucagon-stimulated cyclic AMP levels in isolated hepatocytes. Endocrinology, 101, 236-249.

CARO J. F., AMATRUDA J. M., 1980. The effects of fasting on glucagon binding and action in isolated rat hepatocytes. Metabolism, 29, 732-738.

DESBUQUOIS B., 1975. Iodoglucagon. Preparation and characterization. Eur. J. Biochem., 53, 569-580.

EISENSTEIN A. B., STRACK I., 1978. Increased glucagon secretion in protein-fed rats : effects of refeeding a normal diet. Proceed. Soc. exp. Biol. Med., 158, 578-581.

EISENSTEIN A. B., STRACK I., GALLO-TORRES H., GEORGIADIS A., MILLER O. N., 1979. Increased glucagon secretion in protein-fed rats : lack of relationship to plasma amino acids. Am. J. Physiol., 236, E20-E27.

FEHLMANN M., LE CAM A., FREYCHET P., 1979. Insulin and glucagon stimulation of amino acid transport in isolated rat hepatocytes. J. biol. Chem., 254, 10431-10437.

FEHLMANN M., MORIN O., KITABGI P., FREYCHET P., 1981. Insulin and glucagon receptors of isolated rat hepatocytes. Comparison between hormone binding and amino acid transport stimulation. Endocrinology, 109, 253-261.

FLEISCHER S., KERVINA M., 1974. Subcellular fractionation of rat liver, 6-40. In FLEISCHER S., PACKER L. Methods in Enzymology, vol. 31, part A, Acad. Press, New York, San Francisco, London.

FOUCHEREAU-PERON M., RANCO F., FREYCHET P., ROSSELIN G., 1976. Effect of feeding and fasting on the early steps of glucagon action in isolated rat liver cells. Endocrinology, 98. 755-760.

FREEMAN D., Mc CORKLE K., SRIKANT C. B ., 1977. Effect of hyperglucagonemia on glucagon binding and biologic activity. Diabetes, 26, 366.

FREYCHET P., ROSSELIN G., RANCON F., FOUCHEREAU M., BROER Y., 1974. Interactions of insulin and glucagon with isolated rat liver cells. Binding of the hormones to specific receptors. Horm. Metab. Res., 5, 72-78.

FULLER R. W., BROMER W. W., SNODDY H. D., BAKER J. C., 1975. Regulation of enzyme activity by glucagon: increased hormonal activity of iodinated glucagon. Adv. Enzym. Reg., 13, 201-215.

GERICH J. E., 1976. Control of pancreatic IRG secretion in vivo. Metabolism, 25, 1437-1441.

GILL R. D., HART I. C., 1979. The effect of dietary composition on the binding of insulin and glucagon to goat hepatocytes. Biochem. Soc. Trans., 7, 910-911.

GILL R. D., HART I. C., 1980 . Properties of insulin and glucagon receptors on sheep hepatocytes : a comparison of hormone binding and plasma hormones and metabolites in lactating and non-lactating ewes. J. Endocr., 87, 237-247.

GILL R. D., HART I. C., 1981. Insulin and glucagon binding to hepatocytes in relation to circulating hormones and metabolites in goats maintained on different diets. Horm. Metab. Res., 13, 603-609.

GIORGIO N. A., JOHNSON C. B., BLECHER M., 1974. Hormone Receptors. Properties of glucagon binding proteins isolated from liver plasma membranes. J. biol. Chem., 249 , 428-437.

GRIZARD J., ARNAL M., PION R., 1980. Influence de I'hyperinsulinémie sur les récepteurs d'insuline dans le foie du rat en croissance soumis à une restriction énergétique. Reprod. Nutr. Dévelop., 20, 311-321.

GRIZARD J., PRUGNAUD J., ARNAL M., PION R., 1975. Effet de l'insuline sur la composition corporelle et les teneurs en acides aminés libres du sang, du foie et du muscle 
du rat en croissance soumis à une restriction énergétique. Ann. Biol. anim. Bioch. Biophys., 15, 569-582.

JARROUSSE C., LARDEUX B., BOURDEL G., GIRARD-GLOBA A., ROSSELIN G., 1980. Portal insulin and glucagon in rats fed proteins as a meal : immediate variations and circadian modulations. J. Nutr., 110, 1764-1773.

LOCKWOOD D. H., EAST E. L., 1978. ( $\left.{ }^{125} \mathrm{I}\right)$ glucagon binding by liver membranes from young and adult rats. Diabetes, 27, 589-591.

LOWRY O. H., ROSEBROUGH N. J., FARR A. L., RANDALL R. J., 1951. Protein measurement with the Folin phenol reagent. J. biol. Chem., 193, 265-275.

MARTIN-REQUERO A., PEREZ-DIAZ J., AYUSO-PARRILLA M. S., PARILLA R., 1979. On the mechanism of the glucagon-induced inhibition of hepatic protein synthesis. Arch. Biochem. Biophys., 195, 223-233.

NEVILLE M. D. Jr., 1968. Isolation of an organ specific protein antigen from cell-surface membrane of rat liver. Biochim. biophys. Acta, 154, 540-552.

NOTTEY J. J., ROSSELIN G., 1971. Monoiodoglucagon : préparation, isolement, identification, contrôle radio immunologique. C.R. Acad. Sci. Paris, sér. D, 273, 2118-2121.

PERET J., FOUSTOCK S., CHANEZ M., BOIS-JOYEUX B., ASSAN R., 1981. Plasma glucagon and insulin concentrations and hepatic phosphcenolpyruvate carboxykinase and pyruvate kinase activities during and upon adaptation of rats to a high protein diet. J. Nutr., 111. 1173-1184.

PINGOUD V. A., PETERS F., HAAS T. D. U., TRAUTSCHOLD I., 1982. A quantitative analysis of glucagon binding to isolated intact neonatal and adult rat hepatocytes on the basis of two different binding models. Biochim. biophys. Acta, 714, 448-455.

RÉRAT A., DESMOULIN B., 1970. Influence d'une restriction alimentaire, énergétique et azotée sur la croissance et la composition corporelle du rat blanc. Ann. Zootech., 19, 103115.

SNEDECOR G. W., COCHRAN W. G., 1971. Methodes statistiques, ACTA ed., Paris.

SONNE O., BERG T., CHRISTOFFERSEN T., 1978 . Binding of ${ }^{125}$-labelled glucagon and glucagonstimılated accumulation of adenosine $3^{\prime}: 5^{\prime}$-monophosphate in isolated intact rat hepatocytes. J. biol. Chem., 253, 3203-3210.

SRIKANT C. B., FREEMAN D., Mc CORKLE K., UNGER R. H., 1977. Binding and biologic Activity of glucagon in liver cell membranes of chronically hyperglucagonemic rats. J. biol. Chem., 252, 7434-7436.

UNGER R. H., 1972. Insulin/glucagon ratio. /srae/ J. med. Sci., 8, 252-257. 